Relations industrielles

Industrial Relations

\title{
Church, Roy A. and Quentin Outram, Strikes and Solidarity: Coalfield Conflict in Britain 1889-1966
}

\section{Stephanie Tailby}

Volume 54, numéro 4, 1999

URI : https://id.erudit.org/iderudit/051283ar

DOI : https://doi.org/10.7202/051283ar

Aller au sommaire du numéro

Éditeur(s)

Département des relations industrielles de l'Université Laval

ISSN

0034-379X (imprimé)

1703-8138 (numérique)

Découvrir la revue

Citer ce compte rendu

Tailby, S. (1999). Compte rendu de [Church, Roy A. and Quentin Outram, Strikes and Solidarity: Coalfield Conflict in Britain 1889-1966]. Relations industrielles / Industrial Relations, 54(4), 836-838. https://doi.org/10.7202/051283ar

Tous droits réservés (C Département des relations industrielles de l'Université Laval, 1999
Ce document est protégé par la loi sur le droit d'auteur. L'utilisation des services d'Érudit (y compris la reproduction) est assujettie à sa politique d'utilisation que vous pouvez consulter en ligne.

https://apropos.erudit.org/fr/usagers/politique-dutilisation/ 
rendre justice à la variété des informations et à la richesse des observations qu'il renferme sur la façon de résoudre, par les partenaires sociaux européens, le dilemme de la protection de l'emploi (sécuritê) dans une économie aux exigences de productivité et d'efficacité (flexibilité) sans cesse relevées. Le lecteur moins familier avec les expériences européennes pour la promotion de l'emploi y trouvera plusieurs présentations éclairantes et des observations fort stimulantes. Il sera cependant dérouté par l'organisation de l'ouvrage qui rend la synthèse du propos fort difficile. L'auteure ne propose pas à la fin de chaque chapitre les lignes directrices qu'il faudrait retenir des nombreuses observations qui y sont faites. Pour ajouter à la difficulté, dans plusieurs chapitres, on revient sur les expériences des pays (pas toujours les mêmes?) dont on présente et discute des aspects différents mais complémentaires du dialogue social entre les partenaires. Pour avoir une compréhension plus complète de l'expérience, il faut retoumer fréquemment au contenu des autres chapitres du livre (souvent à la suggestion de l'auteure). Enfin, Edva Sarfati ne présente pas le cadre conceptuel qui serait sous-jacent à sa démarche. En réalité, l'ouvrage se limite le plus souvent à décrire et à commenter de nombreux cas de négociation ou de législation pour la protection de l'emploi. La démonstration des succès de ces expériences de dialogue social ou des insuccès des stratégies de flexibilité du marché du travail est malheureusement loin d'être toujours convaincante. Elle s'appuie d'ailleurs (chapitre 6) plus souvent sur les résultats d'autres recherches que sur ceux de l'étude qui nous a été soumise.

ANDRÉ BEAUCAGE

Département de relations industrielles Université du Québec à Hull

\section{Strikes and Solidarity : Coalfield Conflict in Britain 1889-1966}

by Roy A. CHURCH and Quentin OUTRAM, Cambridge : Cambridge University

Press, 1998, 314 p., ISBN 0-521-55460-8.

This is an impressive and challenging book which should be of interest not only to coalmining labour historians but to industrial relations scholars more generally and to many industrial sociologists. Roy Church and Quentin Outram argue that while there is now a vast literature relating to coalfield conflict in Britain, serious deficiencies persist in our knowledge of the historical pattern of coalmining strike activity which have obscured understanding of the militancy for which British coalminers have been famed. In setting out to provide a more complete account, they focus on local and domestic strikes which, in terms of frequency and prevalence, constituted the industry's "ordinary" strikes; the large-scale county, regional and national disputes given prominence in much of the literature were important but rare in their incidence. The analysis spans a time-period defined largely by the availability of the main primary source used, that is the official statistical record of strikes and lockouts compiled by the Board of Trade from 1901. As Church and Outram emphasize, it is the "unique degree of disaggregation" of the data contained in these manuscript ledgers that has enabled a much more detailed examination of the forms and variations of strike activity than has been attempted hitherto. Their study aims to explain the causes of strikes and the temporal, spatial and inter-colliery differences in strike activity identified. More ambitiously, it seeks to contribute to the development of a "new labour studies agenda" (p. xvii). In relation to this broader intellectual project, Church and Outram highlight the potential of their methodology which combines "traditional historical research methods and quantitative analysis with 
concepts and medium range theory borrowed from the social sciences" (p. xvi).

The opening chapter reviews briefly past approaches and theoretical orientations to the study of mining strikes. Church and Outram indicate that their aim is to move beyond accounts privileging structural conditions in the analysis of strike activity and to embrace also the role of agency. Their conceptualization of the interplay of structure, organization, consciousness and action, however, becomes evident only as the empirical analysis is developed. Chapters 2 to 4 survey secondary sources in an overview of the development of the British coalmining industry and its labour relations from the mid-nineteenth century, and draw from the literature issues and themes to which the empirical analysis returns.

Chapter 5 examines the statistical data on coalmining strikes assembled from archival sources, focusing largely on the period between the two world wars. It confirms that "domestic" strikes, affecting only a single colliery, accounted for the vast majority of all officially recorded strikes in the industry; emphasizes that the industry's unusual strike-proneness was more a characteristic of some regions than others (Scotland and South Wales were consistently more strikeprone than the industry as a whole and became more strike-prone over the interwar period); and shows that a small proportion of highly strike-prone collieries contributed a significant proportion of all officially recorded domestic strikes. Moreover, it reveals that even in the most strike-prone regions, the relative strikeproneness of particular collieries was largely a transient phenomenon; typically the pattern was "a dramatic upsurge of strike activity which subsided equally rapidly" (p. 91).

The statistical evidence dispels the idea that mineworkers were uniformly and consistently militant, if the term is understood as the propensity to strike, and challenges popular conceptions of the miners' pre-disposition towards solidaristic strike action. Domestic strikes predominated and while participation rates varied, "the prevailing picture in many districts... was one of sectionalism rather than solidarity" (p. 128). Chapters 6 and 7 investigate these patterns in relation to the impressive solidarity which mineworkers achieved in their national disputes with coalowners and government. Durkheim's notion of "mechanical solidarity" is found to be useful in explaining solidarity where this emerged locally, but appropriate "social capital" is identified as a pre-requisite. The concept of "constructed solidarity" is developed to explain the solidarity achieved in regional and national disputes, and the analysis serves to emphasize the critical role of miners' trade unions in the forging of unity among workers whose experiences and interests were otherwise shaped by the industry's extreme diversity in terms of geology and markets, systems of work organization and labour management.

Chapters 8 to 10 select from the coalmining literature theories and hypotheses relating colliery strike-proneness to structural, and also organizational characteristics, and test the explanatory power of these through statistical techniques. Some of the structural theories considered are relatively amenable to quantitative analysis - for example, Kerr and Siegel's "isolated mass" hypothesis and the related idea of the influence of workplace size on strike activity. Others are less easy to translate into quantitative form and some of the proxies used to test the variables considered are questionable. Use of mechanical coal-cutters, for example, is taken as a measure of the level of coalface mechanization, whereas the "theory" under consideration suggests that the introduction of the threeshift system, facilitated by the use of mechanical conveyors, formed the moment for the intensification of coalface supervision and, in turn, the potential for 
worker-management conflict. That no association is found between technology and strike-proneness, however, could be due to factors other than "faulty" measures; interwar commentaries allude to the "speed up" taking place in unmechanized as well as mechanized mines.

Among the characteristics identified as pre-disposing collieries towards strike proneness are union organization (more specifically, high and low union density at workplace and district levels respectively), employment size, family ownership, and the remoteness of company headquarters. As Church and Outram emphasize, however, the results of their statistical analysis do not explain the "transmission mechanisms" by which these "underlying characteristics" were linked to strike activity (p. 187). Chapter 11 seeks to complete the analysis, using a sample of "matched pairs" of collieries with different strike histories in an attempt to hold structural factors constant and to distinguish the role of "agency and action". That it reaches only general conclusions, however, is perhaps inevitable. The analysis is constrained by a lack of appropriate evidence and confronts enormous difficulties in attempting to generalize from collieries which were transiently rather than consistently strike prone.

Chapter 12 examines patterns of strike activity after the Second World War and the British industry's nationalization in 1947. Aspects of continuity (in terms of the duration and size of colliery strikes) and of change (the large increase in the volume of strikes from the late 1930s, and Yorkshire's emergence as a relatively strike-prone region) are noted, although the discussion could be criticized for dwelling on the former. Chapter 13 attempts international comparisons to conclude that available data are insufficient for the task. Chapter 14 brings the various strands of the analysis together.

Strikes and Solidarity is, beyond doubt, an impressive book. It embodies a notion of scholarly endeavour to which academics - irrespective of their particular theoretical orientation - can subscribe, and contributes a more detailed record of the patterns of strike activity in British coalmining than has been attempted hitherto. Its theoretical structure could be made more obvious at the outset ; a fuller review in the opening chapters of studies attending to the interaction of "structure and agency" in their analysis of coalfield conflict, and of the book's own exposition in relation to these, would be useful. Nevertheless, its evaluation of the conceptual coherence and empirical "fit" of a number of the theories which that have structured understanding of coalmining's strike-proneness exposes the limitations of uni-dimensional accounts. Popular conceptions of the miners' innate militancy are unseated and the book highlights as impressive the achievement of mineworkers and their unions in overcoming divisions to unite in national struggles.

STEPHANIE TAILBY

University of the West of England

Bristol, UK

\section{Passive Smoke: The EPA's Betrayal of Science and Policy \\ par Gio B. GoRI et John C. LUIK, Vancouver : The Fraser Institute, 1999, 229 p., ISBN 0-88975-196-X.}

Le sujet du tabagisme en milieu de travail est d'actualité. On assiste présentement à une prolifération de lois, de règlements et de politiques d'entreprises. Mais le tout s'entoure d'une certaine polémique. Quel est l'objectif poursuivi exactement? Enrayer complètement l'usage du tabac? La plupart du temps on répond que c'est plutôt de protéger les droits et la santé des non-fumeurs. Si 